\title{
Gluten hypersensitivities and their impact on the production of gluten-free beer
}

\author{
Małgorzata Gumienna ${ }^{1}\left[\right.$ B $\cdot$ Barbara Górna ${ }^{1}$
}

Received: 27 March 2020 / Revised: 18 July 2020 / Accepted: 25 July 2020 / Published online: 6 August 2020

(c) The Author(s) 2020

\begin{abstract}
This article consists of a study of the literature and an assessment of available data on the production of gluten-free beer and its constituents. The article shows how the FAO/WHO Codex Alimentarius Commission for Nutrition and Foods for Special Dietary Uses defines celiac disease, gluten-free products, and gluten-free beer. It describes diet-dependent diseases, which require a gluten-free diet, and groups of potential consumers of gluten-free beer. This article describes the use of oats as a raw material for the production of brewing malt and its usefulness in the production of beer. It specifies how the technological process of standard beer production needs to be modified so that the product meets the requirements of patients with celiac disease. The article also provides an overview of literature data on the production of gluten-free beer from pseudocereal malts, such as sorghum malt, buckwheat malt, amaranth malt, and quinoa malt.
\end{abstract}

Keywords Celiac disease $\cdot$ Gluten-free beer $\cdot$ Hypersensitivities gluten and wheat $\cdot$ Pseudocereals

$\begin{array}{ll}\text { Abbreviations } \\ \text { CD } & \text { Celiac disease } \\ \text { GFD } & \text { Gluten-free diet } \\ \text { EmA } & \text { Endomysial Antibody Assay } \\ \text { tTG } & \text { Tissue transglutaminase } \\ \text { DGP } & \begin{array}{l}\text { Direct antibodies against deamidated gliadin } \\ \text { peptides }\end{array} \\ \text { TGs } & \text { Transglutaminases } \\ \text { GSE } & \text { Gluten-sensitive enteropathy } \\ \text { DLG } & \text { German Agricultural Society } \\ \text { IgA } & \text { Immunoglobulin A } \\ \text { IgE } & \text { Immunoglobulin E } \\ \text { PEP } & \text { Prolyl endopeptidase } \\ \text { AN-PEP } & \text { Aspergillus niger Prolyl endopeptidase } \\ \text { FDA } & \text { Food and Drug Administration } \\ \text { NCGS } & \text { Non-celiac gluten sensitivity }\end{array}$

Małgorzata Gumienna

malgorzata.gumienna@up.poznan.pl

1 Department of Fermentation and Biosynthesis, Faculty of Food Sciences and Nutrition, Poznan University of Life Sciences, Wojska Polskiego 31, 60-624 Poznan, Poland

\section{Introduction}

Cereal crops are a major food source for mankind. Wheat, rice, and barley are among the major cereal crops grown worldwide [1]. The dietary components of cereals, such as lipids, carbohydrates, and proteins, play an instrumental role in processing and nutritional quality for food [2]. Cereal storage proteins constitute about $8-15$ percent of total flour weight and can be classified into albumins, globulins, gliadins, and glutenins, on the basis of their solubility. Of these fractions, monomeric gliadins and polymeric glutenins constitute the gluten proteins [3, 4], but mainly the former are responsible for adverse reactions on the part of the human immune system. Gluten proteins have an unusual chemical composition. They contain large amounts of prolamin and glutamine, which, respectively, make up about $15 \%$ and $35 \%$ of amino acid residues [4]. These amino acids are highly resistant to human gastrointestinal digestion, and in genetically predisposed persons, their contact with the intestinal mucosa triggers an immune response $[4,5]$. This response to gluten is initiated by tissue transglutaminase, (tTG) an enzyme that deamidates the gluten peptides present in the small intestinal human mucosa. Deamidated gliadin peptides are then detected by antigen-presenting cells that are activated, leading to the proliferation of gluten-specific activated cytotoxic $\mathrm{T}$ cells. This immune response results in the destruction of 
the small intestinal mucosa. The storage proteins of barley and rye are very similar to those of wheat, and also trigger this response [5]. The most common wheat-related disorders associated with gluten ingestion are celiac disease (CD) and non-celiac gluten/wheat sensitivity (NCGS/WS), both of which result in impaired quality of life and significant morbidity in individuals. Wheat allergy is another condition that arise from contact with, inhalation of, or ingestion of wheat, and is associated with gluten and with other proteins and carbohydrates present in wheat-particularly, fermentable oligo-, di- and monosaccharides and polyols (FODMAPs). Specific clinical manifestations can be observed in each of these disorders, with some peculiar immunogenic pathways involved in their development [4-6]. Strict adherence to gluten free foods is the only remedy currently known for patients with CD and NCGS. This diet excludes a wide range of products containing gluten fractions from wheat, rye, barley, and oats. Beer is a product that is strictly excluded from the diet [7-9]. Beer is not a necessary product in the everyday diet for the normal function of the body, but it may give variety to the diet. The consumption of beer is increasing year on year [10]. This market niche has encouraged researchers to look for alternatives to traditional brewing ingredients that could be used in the production of gluten-free beer. There have been attempts to use oat grains to produce malt with traditional methods and to mash malts in modified technological processes, so as to make the final product which would be acceptable to consumers. There have been studies on the enzymatic activity of malts, the effect of commercially available enzymatic preparations, and the gluten-free beer brewing process [9]. Recent research findings have additionally motivated researchers to make attempts to develop new products, for example based on oats. According to the FAO / WHO Food Code, oats are not recognised as gluten cereals; their high contamination with grains of other cereals such as wheat, rye, barley make them dangerous in the diet of people suffering from celiac disease. Gluten-free diets are low in vitamins and minerals; to answer this, the production of gluten-free oats was initiated in Finland and Canada; these could serve as a valuable dietary supplement for people suffering from celiac disease. The cultivation of gluten-free oats is strictly monitored at every stage to prevent contamination with gluten grains $[11,12]$ There have also been attempts to use sorghum and pseudocereals such buckwheat, amaranth, and quinoa, as they have favourable chemical compositions [13] and are commonly used to make gluten-free products [13, 14].

The purpose of this review is to point out possible uses of typical and unusual cereal raw materials in the production of gluten-free beer for people with a problematic immune system response to gluten.

\section{Hypersensitivities to gluten and wheat}

\section{Celiac disease}

CD (morbus visceralis, nontropical sprue, gluten enteropathy, or gluten-dependent enteropathy) is an immunemediated systemic disease triggered by exposure to gluten and manifested by small intestinal enteropathy and gastrointestinal and extra-intestinal symptoms. It is characterised by chronic intolerance of foodstuffs containing gluten [12, 15-19]. About $1 \%$ of the world's population is affected by $\mathrm{CD}$, but there are differences between and within countries. In the US, celiac disease is more frequent among non-Hispanic whites than among non-Hispanic blacks and Hispanics. Its prevalence in Asian countries is overall comparable to that in Europe, but varies largely by frequency of wheat intake. Accordingly, the prevalence of is high in Western Asia and Northern India, but lower in South India and South and South Eastern Asia, where rice is the staple food [20].

Gluten is an alcohol-soluble fraction of storage proteins in cereals, already discussed. Depending on the cereal, proteins of the prolamin fraction have specific names: gliadin (in wheat), hordein (in barley), secalin (in rye) or avenin (in oat) [21-25]. Gluten is toxic to patients with celiac disease. It causes villous atrophy in the small intestine. Villi are elements of the small intestinal mucosa. The atrophy results in malabsorption and clinical symptoms. Celiac disease is not an allergy, but an incurable disease. The only therapy is a strict, rigorous life-long gluten-free diet $[12,17]$. The incidence of celiac disease is independent of age, but is higher in women. When untreated, CD may cause serious health problems, such as osteoporosis, mental disorders, infertility, and gastrointestinal cancer $[12,19]$. There has been considerable confusion and a lack of consensus on the diagnostic criteria for CD and related conditions. Experienced doctors at the 14th International Celiac Disease Symposium in Oslo proposed 26 definitions covering a series of vague symptoms differentiating disease states. Full-blown celiac disease, oligosymptomatic, and latent celiac disease were distinguished from gluten sensitivity without celiac disease (NCGS) and gluten intolerance $[26,27]$. The following symptoms can be observed in full-blown celiac disease: pain, distention, enlarged abdominal circumference, steatorrhoea or watery diarrhoea, occasional constipation, loss of body weight, developmental disorders in children (chiefly short stature), changeable disposition (hyperactivity or fatigue and apathy), states of depression, and symptoms of deficiency caused by malabsorption (chiefly iron deficiency, but also deficiency of vitamins and folic acid) [12, 17, 24]. It is more difficult to diagnose oligosymptomatic celiac disease 
due to nonspecific parenteral symptoms, which sometimes occur individually. It may develop latently for many years and cause health problems that are apparently unrelated to the disease; sometimes, these are the only symptoms [12]. There are no intestinal lesions or other symptoms in latent celiac disease, but it is possible to detect antibodies in the blood [12,13]. The diagnostic process of celiac disease involves serological tests which measure the concentration of the following antibodies [26]:

- against smooth muscle endomysium (Endomysial Antibody Assay; EmA),

- against tissue transglutaminase (tTG),

- against deamidated gliadin peptides (DGP).

Apart from that, a small intestine biopsy can be carried out $[12,28]$. If the blood test is positive, the diagnosis must be confirmed by examining a small sample of the intestinal lining with a microscope. The sample (called a biopsy) is usually collected during an upper endoscopy, a test that involves swallowing a small flexible instrument with a camera. The camera allows the physician to examine the upper part of the gastrointestinal system and to remove a small piece (biopsy) of the small intestine. The biopsy is not painful [29]. Specimens are collected and assessed for their degree of villous atrophy, according to the Marsh classification, which indicates the severity of villous atrophy [12, 28]. At present, the only known therapy for patients with celiac disease is a strict life-long gluten-free diet. Usually, symptoms completely disappear after having established a gluten-free diet [30].

\section{Duhring's disease}

Duhring's disease or dermatitis herpetiformis is a form of gluten intolerance which manifests as an autoimmune blistering dermatosis with a characteristic polymorphic, itchy rash [30]. The autoimmune process targeting transglutaminases (TGs) is connected with asymptomatic or mild symptoms of gluten-sensitive enteropathy (GSE) [31]. Duhring's disease is often diagnosed in the families of patients with coeliac disease. The symptoms usually occur between the ages of 14 and 40 [32-34]. The most common symptoms are: itchy vesicular eruptions, erythema, and papules resulting in scabs and scars on the knees, elbows, in the sacral region, on the buttocks, on the torso in the scapular region, on the face and on the hair-covered skin of the head. Apart from cutaneous symptoms, about $10 \%$ of patients also have gastrointestinal symptoms as a consequence of total or almost total villous atrophy. The disease can also manifest atypical symptoms such as anaemia, weakness, and depression. Most patients do not produce the antibodies that are characteristic of coeliac disease. A strict gluten-free diet is essential to patients with Duhring's disease [12, 32, 33]. An accessory therapy involves limiting the consumption of iodine, as large amounts of iodine can lead to the formation of significant deposits (blisters), and can worsen the symptoms of skin lesions. Iodine intake should, thus, be minimized, but only under medical supervision. When the IgA deposits have disappeared from the patient's skin as a result of a gluten-free diet, iodine should no longer be a problem in patients [34]. If the symptoms persist, additional pharmacotherapy is applied $[12,32,33]$.

\section{Wheat allergy}

$\mathrm{CD}$ and gluten allergy are separate health problems which should not be identified with each other. It is estimated that $10-25 \%$ of patients with food allergies are allergic to gluten, which indicates the high allergenicity of this protein fraction $[23,35]$. Instant and delayed gluten allergy are distinguished depending on the time between the consumption of a meal and the occurrence of an allergic reaction. Instant gluten allergy occurs from a few minutes up to one hour following the consumption of a meal and depends on glutenspecific IgE antibodies. Vomiting, diarrhoea, anaphylactic shock, urticaria, watery runny nose, bronchospasm, and skin lesions typical of atopic dermatitis can also occur [12, 35]. On the other hand, delayed gluten allergy is independent of IgE antibodies, and its symptoms and course depend on the patient's age. In children, the allergy usually manifests as diarrhoea and atopic dermatitis, with gastrointestinal and respiratory problems being less frequent. These symptoms can be observed after consuming minimal amounts of gluten. This type of allergy may continue for a long time, but most children recover from it as they grow older. In adults, the allergy manifests as urticaria, anaphylactic shock, and diarrhoea [12, 23, 35]. It is important that detailed tests are conducted to exclude celiac disease form the diagnosis [23].

\section{Non-celiac gluten/wheat sensitivity (NCGS)}

The diagnosis of non-celiac gluten sensitivity (NCGS) has been introduced recently to account for a potentially common disease seen in patients who claim reactivity to gluten but who lack the characteristics of celiac disease. CD is characterised by antibody reactivity toward the autoantigen transglutaminase 2 (tTG), histological abnormalities of the small intestine, and an almost obligatory genetic haplotype (HLA-DQ2 or DQ8). The diagnosis of NCGS is based largely on the clinical suspicion of a hyperreactivity to gluten and the absence of CD features [27, 36, 37]. Gluten sensitivity is defined as undesirable symptoms upon consumption of gluten (best checked with a provocation test), but where celiac disease has been excluded by negative antibodies results, gluten allergy has been excluded by 
normal IgE concentration [38], and there no symptoms of villous atrophy (Marsh 0 or 1). Gluten sensitivity is usually observed in adults and manifests as abdominal pain, headache, rash, eczema, permanent fatigue, confusion, diarrhoea, flatulence, constipation, anaemia, pain and numbness of the limbs, weakness, syncope, esophagitis, nausea, vomiting, stomach rumble, and inflammation of the tongue. Usually, a few symptoms occur simultaneously within a few hours or days following the consumption of a meal containing gluten. It is estimated that this problem can be observed in a few percent of the population, and so it is probably much more common than celiac disease. Presumably, not all patients with NCGS require as restrictive diet as is needed for celiac; a low-gluten diet may be sufficient. The lack of a specific disease marker makes it difficult to identify a patient's tolerance to food contaminated with gluten $[37,39,40]$.

\section{Enzyme therapy of celiac disease}

Gluten is ubiquitous and used extensively in the food industry, meaning that many food items may be contaminated with gluten. Even homemade food may be contaminated with traces or moderate amounts of gluten. Even a small amount of gluten is immunogenic to the susceptible host. Maintenance of a gluten-free diet (GFD) is quiet demanding and requires a considerable amount of motivation from patients and their families. However, GFD alone is frequently insufficient to control the symptoms and to prevent mucosal damage that can result from unintentional gluten exposure. Adherence to the diet can pose a challenge and lead to frustration, and many $\mathrm{CD}$ patients are exposed to gluten inadvertently via contamination of food, medications, and supplements. Owing to the substantial difficulty of adherence to a GFD, most patients with $\mathrm{CD}$ are very interested in non-dietary therapies for the management of their condition. There is, thus, a need to develop alternative or adjuvant therapies for the patients with celiac disease [41, 42]. Dietary proteins reaching the intestinal lumen are digested by gastric pepsin and pancreatic proteases, and are further degraded by brush border enzymes (dipeptidases, tripeptidases) into amino acids, dipeptides, or tripeptides, which are transported across the enterocytes. The principal toxic components of gluten are proline-rich and glutamine-rich peptides that are resistant to proteolysis by gastric, pancreatic, and intestinal brush border membrane enzymes. Humans do not have an enzyme capable of breaking the bond between proline and glutamine. Gluten protein is, thus, not digested completely, and partial digestion of gluten leads to the creation of multiple peptides, which induce an immune reaction in genetically predisposed people, causing the symptoms of celiac disease [43]. One appealing approach to CD therapy is, thus, to use enzymes that can break gluten's proline-glutamine bond [44]. Prolyl endopeptidases (PEPs) are capable of cleaving bonds between proline and glutamine, and can be derived from microorganisms such as Flavobacterium meningosepticum and Sphingomonas capsulate [45]. Most of these enzymes, however, are irreversibly inactivated in the stomach by pepsin and the acidic $\mathrm{pH}$, and do not reach in the intestine. Currently, only one agent, DSM Tolerase ${ }^{R} G$, with a positive effect on the residual gluten breakdown is commercially available.

Tolerase ${ }^{R} \mathrm{G}$ or Aspergillus niger prolyl endoprotease (AN$\mathrm{PEP}$ ) is a proline-specific digestive enzyme. The enzyme is designed to have optimal activity under the harsh conditions of the stomach. It is the first and only enzyme shown to be effective in a human clinical study [46]. It is commercially available in the USA, Canada, and Europe. It is active at a low $\mathrm{pH}(\mathrm{pH} 2-8$, optimal activity $\mathrm{pH} 4-5)$ and is resistant to degradation by pepsin. Its capacity to degrade gluten into non-immunogenic peptides has been shown in a number of in vitro and in vivo studies. Salden et al. [47] showed that AN-PEP efficiently degraded gluten $(4 \mathrm{~g})$ in the stomach of healthy subjects when added to an intragastrically infused meal. It was recently shown that this also occurred when AN-PEP was administered in tablet form, together with a composite meal, in self-reported non-celiac gluten-sensitive subjects. That study investigated the efficacy of AN-PEP to degrade a small amount of gluten (circa $0.5 \mathrm{~g}$ ), which was intended to represent an unintentional intake of gluten. Although the enzyme has not been specifically been tested in celiac disease patients for this purpose, it can be assumed that the physiology behind the gluten degradation by such an enzyme in the stomach does not differ between patients with celiac disease, non-celiac gluten sensitivity, and healthy subjects [48].

Kuma030 is a promising preparation that could make life easier for patients on a gluten-free diet. A kumamolisin variant with high proteolytic activity and stability is of great interest for industrial and therapeutic applications. Kuma030 is an engineered glutenase developed by the Institute for Protein Design, University of Washington. It is a serine endoprotease with optimal activity over the $\mathrm{pH}$ range of 2-4 and at $37{ }^{\circ} \mathrm{C}$; it is, therefore, suitable for use in the gastric environment [49]. In 2012, a variant named Kuma010 was obtained through computational design against the S1 binding pocket of wild-type kumamolisin from the acidophilic bacterium, Alicyclobacillus sendaiensis, which represented 116-times higher proteolytic activity for a model gluten tetrapeptide than the wide-type protease. Following this research, the more efficient variant Kuma030 was obtained using Rosetta Molecular Modelling Suite to reconstruct the active sites of Kuma010 [49].

Kuma030 can degrade more than $99.97 \%$ degradation of $10,000 \mathrm{ppm}$ gluten leads to $30 \mathrm{ppm}$ remaining gluten, and this appears not to be sufficient to produce gluten-free 
material $(<20 \mathrm{ppm})$. Moreover, Kuma030 also exhibits strong gluten degradation ability against actual food, such as wheat bread and wheat beer, thus indicating its potential application in oral therapeutic for celiac disease [50].

\section{Definition of gluten-free food}

The gluten-free diet involves completely avoiding the consumption of products containing wheat, rye, and barley. In Poland, in accordance with EU legislation, the diet also requires avoiding the consumption of oats, triticale, and spelt. At present, there is a great deal of controversy concerning the position of oats in a gluten-free diet. Avenin is an oat protein belonging to prolamin type proteins. Researchers have indicated that it does not trigger the same celiacspecific reaction from the immune system as do the proteins contained in wheat, rye, and barley. The results of research into the dangers of avenin consumption show that it differs from other prolamins in its amino acid composition [51], and it may, thus, be much less toxic. Some countries, such as Finland and the United Kingdom, allow the consumption of specially tested and certified oats in a gluten-free diet, though the amount that can be consumed is strictly limited. According to the recommendations of the UK celiac society (Celiac UK), the maximum allowable daily dose of oats is $50 \mathrm{~g}$ for adults and $25 \mathrm{~g}$ for children. Many other countries resist permitting the consumption of oats in a gluten-free diet as they are typically heavily contaminated with gluten in technological processes. It is necessary to consider each patient's individual gluten tolerance, and particular attention needs to be accorded to patients with regenerated villi, who must limit their daily consumption [9]. The strict guidelines on maintaining a gluten-free diet have led to the definition of gluten-free food. The FAO/WHO Codex Alimentarius Commission for Nutrition and Foods for Special Dietary Uses has been working on requirements concerning this food for a number of years. This work represents a set of general nutritional standards are accepted and observed by most European countries. The requirements for gluten-free food were listed in a document published in 1979, amended in 1983, and most recently updated in 2008 . The guidelines were incorporated in Commission Regulation (EC) No. 41/2009 and, having undergone amendment, are regulated by the provisions of Commission Implementing Regulation (EU) No 828/2014 of 30 July 2014. Key terms of the Act are the definition of gluten: „Gluten: a protein fraction from wheat, rye, barley, oats or their crossbred varieties and derivatives thereof, to which some persons are intolerant and which is insoluble in water and $0.5 \mathrm{M}$ sodium chloride solution" [52-54]. According to this Regulation, glutenfree products are those that naturally contain no gluten, or contain gluten at a concentration lower than $20 \mathrm{ppm}$, or
$20 \mathrm{mg} / \mathrm{kg}$ of product. Only products containing less than $20 \mathrm{ppm}$ of gluten on the package may include the designation 'gluten-free product', which should be in the immediate vicinity of the product name. The Association of European Celiac Societies (AOECS) guidelines define the use of the device of a crossed-out ear of corn to guarantee consumer safety; this can only be used by companies that meet the relevant criteria. Naturally, gluten-free products should not be labelled as products of special dietary purpose, but they can be described as products naturally not containing gluten, provided that the requirements of gluten-free food are met [52]. Some people intolerant to gluten may tolerate small amounts of gluten within the limits of the specified values. In order for consumers to find food products that meet their needs and individual sensitivity thresholds, a selection of products with varying low gluten contents should be available. Such products should be appropriately labelled. The phrase 'very low gluten content' can only be used for products that have been specially processed to reduce the gluten content to not exceed $100 \mathrm{mg} / \mathrm{kg}$ of gluten in food sold to the final consumer [52]. The guidelines define gluten-free food as follows: foodstuffs containing or made from one or more ingredients not containing wheat (meaning all Triticum species, such as durum wheat, spelt, and kamut), rye, barley, oats, or their crossbred varieties, which contain a level of gluten not exceeding $20 \mathrm{mg} / \mathrm{kg}$ in total, based on the food as sold or distributed to the final consumer, and/or foodstuffs containing one or more ingredients made from wheat (meaning all Triticum species, such as durum wheat, spelt, and kamut), rye, barley, oats or their crossbred varieties, which were specially processed so as to reduce the level of gluten to no more than $20 \mathrm{mg} / \mathrm{kg}$ in total, based on the food as sold or distributed to the final consumer [53-58].

In more straightforward terms, a gluten-free product is one whose total content of gluten does not exceed $20 \mathrm{mg} /$ $\mathrm{kg}$. Additionally, very-low-gluten products are defined as foodstuffs containing one or more ingredients made from wheat (meaning all Triticum species, such as durum wheat, spelt, and kamut), rye, barley, oats or their crossbred varieties, which have been specially processed so as to reduce the level of gluten to $20-100 \mathrm{mg} / \mathrm{kg}$ in total, based on the food as sold or distributed to the final consumer [52, 53]. Shops offer an increasingly wide range of gluten-free products, such as rice wafers, cold cuts, sausages, pasta, sticks, cakes, bread, and even ready mixtures of flour for baking gluten-free bread $[24,55]$.

\section{Gluten-free beer}

According to these European Commission guidelines on gluten-free food, beer made from pseudocereal malts and atypical cereal malts not containing gluten-as well as beer 
made from typical brewing malts and other malts containing gluten which have been specially technologically processed so as to reduce the level of gluten to no more than $20 \mathrm{mg} /$ $\mathrm{kg}$ - can be described as gluten-free beer. We can also define very-low-gluten beer as beer made from brewing malts which have undergone special technological processing so as to reduce the level of gluten to no more than $20-100 \mathrm{mg} / \mathrm{kg}$ $[9,17]$. However, some producers find removing gluten from brewing malts, such as barley malt and wheat malt, to be a complex and expensive processes, which increases the price of the final product. This is the main reason for research into the development of effective means of producing beer from gluten-free malts. There is some controversy about certifying beers from which gluten has been removed as, according to some recent reports, these can cause disease symptoms in some patients with celiac disease-unlike beers made from cereals which naturally do not contain gluten. The US Food and Drug Administration (FDA) do not allow beers from which gluten has been removed to be labelled gluten-free products [56]. One factor that contributes to the controversy is that the quantitative determination of hydrolysed hordein protein by ELISA is effective for intact proteins, but not for hydrolysed proteins. This results in an underestimation of the gluten content after mashing and fermentation. The FDA, thus, does not permit beers brewed from raw materials containing gluten to be considered gluten-free products $[56,57]$

The following atypical cereal malts can be used for the production of gluten-free beer: oat malt, rice malt, maize malt, sorghum malt, and millet malt. Gluten-free beer can also be made from pseudocereal malts, such as buckwheat malt, quinoa malt, and amaranth malt [17, 57, 58]. At present, the research into the production of gluten-free beer from sorghum malt, oat malt, buckwheat malt, quinoa malt, and amaranth malt is most advanced [59-61]. These malts have high starch contents and moderate protein levels [51].

However, techniques for brewing beer from many cereals other from barley are not yet well developed. However, encouraging results have recently been achieved brewing with rice malt in a pilot plant, resulting in an alcoholic product with a sensory profile similar to a barley malt beer in terms of aroma, taste, and mouthfeel, though the beer was blander and featured low foam stability [62].

As an alternative, complex and costly filtration and enzymatic techniques can be used to condition the malts, to boost processes leading to the precipitation of proteins during mashing, fermentation, and stabilisation [63, 64]. Another alternative technique uses silica gel in the fermentation stage of the brewing process to selectively remove proteins, practically without any effect on valuable yeast nutrients (such as free amino-nitrogen and foam-causing proteins), leading to gluten reduction in the subsequent stabilization stage [65]. Although silica is a generally recognised as safe (GRAS) food additive in the US and Europe, its use adds to cost and process complexity [65]. In addition to these drawbacks, the resulting beers tend to differ in aroma and taste from traditional beers brewed with barley malt.

\section{Production from gluten-containing raw materials}

Wheat and barley, as well as rye, are the basic raw materials in ales and lager beers. These cereals show the presence of the octapeptide PQQPFPQQ responsible for allergic reactions. This amino acid sequence contains the PQQP motif characteristic of $\alpha$-gliadin, and the QQPY motif present in the fractions causes celiac disease [4], the only known therapy for which is a strict lifetime gluten-free diet (GFD). Several techniques for producing beer from traditional raw materials have been developed to assist CD sufferers, and also to reduce the costs of raw materials and production [57]. A proline endoprotease is an enzyme that specifically hydrolyses peptide bonds next to a proline residue; it has been hypothesised that such an enzyme could be used to degrade the peptide sequences responsible for celiac disease, as all these toxic epitopes are rich in proline [66]. Van Landschoot [67] has shown that barley malt can be deprived of gluten using a proline endoprotease. In contrast, Guerdrum and Bamforth [68] studied the effect of Aspergillus niger (AN-PEP) prolyl endoprotease on the prolamin level in beer produced from these malts. This enzyme, which is already used in the brewing industry as an anti-turbidity agent (among other uses), breaks down the proline-rich gluten fraction. These authors came to the conclusion that this exogenous enzyme, added during fermentation or to the finished product, can make the beer gluten free without affecting foam stability [66]. Tanner et al. [69], employing mass spectrometry, succeeded in confirming these results. In addition to microbial enzymes, a number of endogenous proteases contained in cereal seeds have been found to destroy immunotoxic gluten peptides. Research has focused on endogenous malt peptidases [57]. From the characteristics of cereal proteolytic enzymes, it appears that proteases are present in resting grains and activate during germination. In addition, some enzymes are synthesised during germination. It seemed from the research of Hartmann et al. [70] that proteases from germinating wheat, rye, and barley interact with the toxic peptides, creating fragments of less than nine amino acids in length. Similar studies conducted by Kerpes et al. [71] and Knorr et al. [72] have shown that barley malt enzymes are capable of degrading the celiac disease peptides PQPQLPYPQPQLPY (P1) and SQQQFPQPQQPFPQQP (P2). In their research, these authors showed that gluten-specific peptidase activity can be significantly increased by altering germination parameters, including the humidity, temperature, and duration of the process. Further research by Kerpes et al. [57] showed degradation of hordein during malting and brewing. 
Endoprotease B2 has been shown to degrade B-, C-, D- and $\gamma$-hordein fractions in beer up to below the defined limit of $20 \mathrm{mg} / \mathrm{kg}$. Considering that gluten-specific peptidases naturally occurring in the grain itself are easy to use, there is no need for genetic engineering; the malting process is well understood, so this research represents a promising alternative to current methods of obtaining gluten-free beer with traditional malts [57, 71].

In addition to enzymatic methods of decreasing gluten levels to below $20 \mathrm{ppm}$, a number of modifications have been introduced into key stages of the technological process. One of these is brewing with conventional barley malt assisted by controlled hydrodynamic cavitation (CHC). Hydrodynamic cavitation technologies have emerged since the 1990s in various technical fields, including the processing of liquid food, and presents benefits such as accelerating extraction processes, disinfection, and energy efficiency [73]. The use of cavitation in the traditional brewing of barley beer has given positive results, which is why it has now been used to produce gluten-free beer [73, 74].

During the development and test of a novel brewing technology based on controlled hydrodynamic cavitation [74], early evidence arose of gluten reduction in wort and finished beer made from $100 \%$ barley malt, under suitable cavitation regimes during both mashing and fermentation. Experimental tests are ongoing, and a number of hypotheses have been advanced pointing to the degradation of proline residues (the most recalcitrant among gluten constituents), leading to a reduction in gluten concentration both in the unfermented wort and during fermentation and maturation-in the latter case due to enhanced proline assimilation by yeasts. Directions for further research include at least verifying experimental results and designing new experiments, extending the range of cavitation regimes, and identifying precise operational parameters for brewing recipes [74].

\section{Atypical cereals used in the production of beer}

\section{Oats}

Oats are a particularly attractive and valuable cereal due to their health-promoting properties [75]. They have been the subject of numerous studies, including nutritional research demonstrating that oats have hypocholesterolemic properties and high levels of dietary fibre, in the form of beta-glucans [11]. The consumption of oats and oats products in the everyday diet reduces total cholesterol and its low-density lipoprotein fractions (LDL), while increasing high-density lipoprotein fractions (HDL) in the blood serum and regulating blood sugar levels. They have antispasmodic, antineoplastic, diuretic, and sedative properties, play a positive role in the cardiovascular system, and strengthen the nervous system $[11,76,77]$. For a long time, oats were considered to contain gluten, and a great deal of controversy and contradicting opinions remains over their role in a gluten-free diet. However, numerous latest clinical trials have shown that most patients with celiac disease tolerate oats very well. It has been demonstrated that the inclusion of oat products in a gluten-free diet adds minerals, fibre, B vitamins, tocochromanol, and essential unsaturated fatty acids [77]. There have been inconsistent clinical findings regarding the question of whether oats can be safely consumed by CD patients, with a handful of studies suggesting that some CD patients possess sensitivity to oat proteins. In contrast, other studies have shown that even large amounts of oats are well tolerated by CD subjects [78]. These results have encouraged research into the production of gluten-free beer from oat malt [79-81]

\section{Oat beer}

Oat beer can be produced by modifying brewing technology to account for the chemical composition and structure of the grain. The high levels of fat in oats may negatively affect the stability of both the beer and its foam [82]. Other problems can be caused by the high protein levels of oats, which reduces the content of starch, a particularly valuable brewing ingredient. Additionally, oats high protein levels may extend soaking time, increase the amount of water absorbed by the grain, and reduce the gravity of the wort, while the concentration of nitrogen compounds remains high. Oats are rich in polyphenolic compounds, which may result in bitter aftertaste and may generate turbidity of the final product. Oats have high levels of fibre, chiefly in the form of $\beta$-glucan, which is a benefit for those with coeliac disease. However, $\beta$-glucan results in a high-viscosity turbid wort; the turbidity will lead to a final product with reduced organoleptic attractiveness to the consumer, and the high viscosity will result in a need to use alternate mash filtration techniques. The germination energy and enzymatic activity of oats are much smaller than in the case of barley. Another problem is the fact that the optimal temperature and $\mathrm{pH}$ for enzymatic activity have not been well investigated. Due to the multiple difficulties in the malting process, there have been numerous studies looking at how to adapt the technological process through correct selection of optimal conditions and enzymatic preparations, so as to produce beer that meets the criteria for foodstuffs of special dietary use and which is acceptable to consumers [81].

Comparative research into the quality of oat malt produced on a laboratory scale and on a small production scale was conducted using standards for the assessment of Pilsner barley malts, using different malting schemes for individual temperature variants. The findings (Table 1) point to trends which should be followed in the further optimisation in consecutive stages of processing. Oats cultivars were selected for the research because they had the most useful chemical 
Table 1 List of selected quality parameters of oat malt and requirements for Class I barley malt [57]

\begin{tabular}{|c|c|c|c|}
\hline \multirow[t]{2}{*}{ Parameter } & \multicolumn{2}{|l|}{ Oat malt } & \multirow{2}{*}{$\begin{array}{l}\text { Requirements for } \\
\text { class I barley malt }\end{array}$} \\
\hline & Malt obtained on a laboratory scale & $\begin{array}{l}\text { Malt obtained in a micro- } \\
\text { malting plant }\end{array}$ & \\
\hline Moisture (\%) & $4.2 \pm 0.33$ & $4.6 \pm 0.21$ & $<4.5$ \\
\hline Extractivity of malt (\% d.m.) & $38.0 \pm 0.70$ & $31.1 \pm 0.59$ & $<79.5$ \\
\hline Color (EBC units) & $6.5 \pm 0.5$ & $5.0 \pm 0.00$ & $<3.5$ \\
\hline $\mathrm{pH}$ value & $6.3 \pm 0.03$ & $6.0 \pm 0.01$ & $<5.9$ \\
\hline Viscosity of the laboratory wort (mPa.s) & $1.8 \pm 0.02$ & $1.7 \pm 0.02$ & $<1.7$ \\
\hline Clarity turbid (EBC units) & Turbid $(>100)$ & $12.3 \pm 0.58$ & Clear or iridescent \\
\hline Total protein in malt (\% d.m.) & $13.0 \pm 0.65$ & $12.8 \pm 0.29$ & $<11.3$ \\
\hline Solube nitrogen (mg/100 g d.m.) & $693.0 \pm 23.16$ & $582.2 \pm 15.39$ & $630 \pm 800$ \\
\hline Kolbach index $(\%)$ & $33.0 \pm 2.34$ & $28.4 \pm 1.12$ & $35 \pm 45$ \\
\hline Free amino nitrogen (mg/100 g d.m.) & $83.0 \pm 7.05$ & $93.3 \pm 8.67$ & - \\
\hline Saccharification time (min) & The mash wasn't saccharified & $15-20$ & $<15$ \\
\hline Diastatic power (WK units) & $63.5 \pm 2.77$ & $107.2 \pm 7.82$ & $>240$ \\
\hline
\end{tabular}

composition for the brewing process. These cultivars had the lowest levels of total protein (about 12.6\%) and relatively low soluble protein content, oscillating around the lower limit required for barley malt. The following scheme was found to be optimal for oat malts: $4 \mathrm{~h}$ of soaking under water, $2 \mathrm{~h}$ of exposure to air with high humidity, $3 \mathrm{~h}$ of soaking under water, and 5 days of germination [79]. Oat malts were analysed with the Congress method for traditional barley malts, as this allowed comparison of the test ingredient with the requirements for standard brewing ingredients. The measurements showed better results for trials conducted on the small production scale. The samples had adequate humidity, which resulted in better loosening. The oat malt produced in the micro-malthouse was of better quality than the malt produced in the laboratory sprouters. However, neither of them possessed the quality parameters of barley malt. As we expected, the oats proved to be less useful for malting [81]. Insufficient extractivity of the oat malts and the low enzymatic activity point to the need to modify the malting, drying, and mashing processes. It is necessary to adjust the temperature profile, the duration of individual enzymatic activity intervals, and to optimise the grist-water ratio. The use of enzymatic preparations in the production of oat wort may result in considerable economic benefits, such as higher efficiency (more complete hydrolysis of the starch and compounds in the oat malt), a shorter production process, less energy outlay due to shorter saccharification time, and facilitation of the process thanks to the reduced viscosity [79-81].

\section{Production from gluten-free raw materials}

Gluten-free beer can also be produced using standard brewing ingredients. An additional stage is added to the process to reduce the gluten levels to no more than $20 \mathrm{mg} / \mathrm{kg}$. However, the process is technologically challenging, as it requires specialised enzymatic processing. At the same time, it increases the cost of production and of the final product. For these reasons, research is ongoing for alternative glutenfree ingredients that could be used to produce gluten-free beer [9]. Apart from the atypical cereal malts, pseudocereal malts from buckwheat, quinoa, and amaranth also meet these requirements. Comparison of selected parameters affecting the beer production process from gluten-free raw materials are shown in Table 2.

\section{Buckwheat}

Buckwheat has high levels of protein with a favourable amino acid composition. It does not contain gluten and is rich in saccharides, fats, dietary fibre, vitamins, and minerals. As it contains rutin and other flavonoids, which can be classed as bioactive compounds, buckwheat can be considered a health-promoting crop. It is often used in the production of gluten-free foodstuffs, such as buckwheat groats, flour, and noodles [83-86]. The beer produced in our pilot was highly turbid, brown in colour, with poor head stability and a bitter taste [87]. The initial mashing process did not undergo complete saccharification. It was necessary to use a more complex mashing procedure with commercial enzymatic preparations of $\alpha$-amylase and glucoamylase. Sparging was impossible because the spent grain was unfavourably positioned at the bottom of the tun, and the efficiency of the process was thus very low, at $54.5 \%$. The fermentation processes as conducted with to the usual parameters. Sensory analysis was conducted according to the guidelines of the German Agricultural Society (DLG) and the beer ageing evaluation followed the Eichhorn method and gave positive 
Table 2 Comparison of selected parameters affecting the beer production process from gluten-free raw materials [63]

\begin{tabular}{|c|c|c|c|c|c|c|}
\hline Paramter & Barley & Beckwheat & Amaranth & Quinoa & Rice & Sorgo \\
\hline Gelatinization temperature $\left({ }^{\circ} \mathrm{C}\right)$ & $58-66$ & $65-72$ & $64-74$ & 64 & $97-91$ & $69-80$ \\
\hline Extractivity of malt (\% d.m.) & $76.0-88.0$ & $61.9-65.3$ & $88.6-91.1$ & 37.7 & $64.3-77.8$ & 68.0 \\
\hline Kolbach index $(\%)$ & $34-45$ & $28-32$ & $15-20$ & 53 & $15-39$ & $20-26$ \\
\hline Saccharification time (min) & $10-15$ & $>20$ & $>60$ & $>20$ & $>30$ & 60 \\
\hline Diastatic power (WK units) & $200-416$ & 72 & Data not reported & 61 & $19-62$ & $77-101$ \\
\hline $\operatorname{Alcohol}^{\mathrm{a}}(\%)$ & $3.6-5.3$ & $3.8-4.7$ & 4.6 & $4.3-4.9$ & $3.6-5.1$ & $2.9-4.6$ \\
\hline Foam stability ${ }^{a}$ (s) & $228-263$ & Data not reported & Data not reported & 319 & $157-182$ & 130 \\
\hline
\end{tabular}

${ }^{a}$ Referred to the final product

results for all organoleptic properties (aroma, purity, taste, and bitterness). Variability in the biochemical properties of buckwheat grain had considerable effect on the optimal parameters of the malting process [88]. We also made attempts to solve the technical problems that occurred during malt production. The optimisation of mashing and wort fermentation were considered to be important. New combinations of enzymatic preparations may solve the mashing problems. A mash filter or rice hulls could be used to solve filtration problems [9]. Given these problems, research into the production of buckwheat beer should continue.

\section{Amaranth}

Amaranth is a pseudocereal with high nutritional and health-promoting value. It is an abundant source of easily assimilable proteins of high biological value, dietary fibre, unsaturated fatty acids, minerals (iron and calcium), and squalene. Amaranth proteins are chiefly composed of albumins and globulins, which composition varies by species of amaranth. Amaranth does not contain gluten [86, 89, 90]. The essential amino acids content is high in the seeds, and the amino acid composition is better balanced than in most cereals. Amaranth is a good source of riboflavin, vitamin E, calcium, magnesium, and iron. The high calcium content of amaranth seeds has special significance for celiacs, due to the prevalence of osteopenia and osteoporosis among newly diagnosed celiac patients [25]. Amaranth seeds and sprouts have significant anti-oxidative activity due to their levels anthocyanins and flavonoids [25, 86]. Due to these properties, amaranth is widely used for designing and producing gluten-free food [25, 83, 89]. Zweytick et al. [87] attempted to malt and brew gluten-free beer using only amaranth malt. The seeds were washed with water at a temperature of $10-15{ }^{\circ} \mathrm{C}$, soaked for $1 \mathrm{~h}$, and then subjected to germination ( 3 days at $15{ }^{\circ} \mathrm{C}$ and with $95 \%$ relative humidity). When the sprouts reached double grain length, they were dried at $80{ }^{\circ} \mathrm{C}$ for $24 \mathrm{~h}$. A double-decoction method was used as the mashing process. At $50{ }^{\circ} \mathrm{C}$, part of the mash was removed to a boiler and heated for $5 \mathrm{~min}$ at $85^{\circ} \mathrm{C}$, before being returned to the mash tun, causing the mash to reach the temperature of the next break $\left(65^{\circ} \mathrm{C}\right)$. The procedure was repeated to obtain a temperature of $71{ }^{\circ} \mathrm{C}$. The whole mash was then heated to $76{ }^{\circ} \mathrm{C}$ and filtered. The wort was boiled for $90 \mathrm{~min}$ and, after cooling to $12{ }^{\circ} \mathrm{C}$, was pitched with yeast. Primary fermentation was carried out at a temperature of $6-12{ }^{\circ} \mathrm{C}$, with secondary fermentation at $4{ }^{\circ} \mathrm{C}$. The beer made, thus, from amaranth malt was slightly cloudy and had a yellow colour. The foam stability was not satisfactory and the beer tasted too bitter [14, 87, 91]. Beer stability was satisfactory. Little data are currently available on amaranth brewing. Amaranth starch has a high gelatinisation temperature and saccharification does not proceed completely [92]. Brewing with amaranth malt gives a low efficiency final beer with a middling alcohol content $[59,93]$. The amaranth malting process needs to be further developed if this grain is to be used in brewing. However, its use as an adjunct in beer is a novelty, and may arouse interest from the consumer [9, $63,92]$.

\section{Quinoa}

Quinoa is characterised by a balanced composition of all nutrients. It has very high levels of protein (but does not contain gluten), as well as of fats, and it presents a favourable amino acid profile. It also contains vitamins, polyphenols, and flavonoids. For these reasons, quinoa is commonly used to produce dietary supplements and gluten-free food [84, 86, 89, 92, 94]. The production of malt and beer from quinoa has also been investigated by Zweytick et al. [87]. A process similar to that used in the production of gluten-free beer from amaranth was used. The quinoa beer, like the beer made from amaranth, was yellow and had a slight turbidity. The foam stability was quite good and the taste was considered acceptable [9, 87, 91, 95].

\section{Rice}

Rice is a staple food for nearly $50 \%$ of the world's population. According to the Food and Agriculture Organization 
(FAO) of the United Nations, global paddy rice production in 2017 was 756.7 million tonnes (502.2 million tons on a milled basis) [96]. Rice does not contain gluten-like proteins, so it is particularly suitable for consumption by individuals with celiac disease. Rice could, thus, serve as a useful raw material in the production of a gluten-free beer-like beverage. In the contemporary beer brewing industry, rice is primarily used as an adjunct in combination with barley malt. As a brewing adjunct, rice has a very neutral flavour and aroma, and when properly converted in the brew-house yields a light, clean-tasting beer [96].

Sensory analysis conducted on rice beers shows a pale yellow colour and a white coarse foam which rapidly collapses. Rice malt beer has a relatively poor character. In sensory tests, a vanillin flavour is revealed. The sensory profile of the rice malt beer was similar to a barley malt beer in aroma, taste and mouthfeel, but more neutral. Advances in malting rice for brewing show encouraging results. Rice is a suitable grain for malting, even though it is often suggested that it is lacking the enzymatic power needed for brewing. Rice malt beer can be produced in a traditional way, leading to well-fermented beers with no off-flavour, and comparable to bottom-fermented beer made from barley malt [96].

\section{Sorghum}

Sorghum is the fifth most produced cereal grain after barley in the world. Its use as a raw material for traditional sour beers and in industrial beer processing in several developing countries is now increasing. Sorghum grains have been suggested as a potential raw material to produce functional foods [97]. An important feature of sorghum is that it does not contain gluten [98-100]. However, in spite of these advantages, sorghum malt causes numerous problems in industrial production. The mash is slow and results in incomplete saccharification. The wort and resulting beer are difficult to filter. Sorghum is chiefly used to produce kafficorn beer and similar products [100]. Insufficient diastatic power is the main problem in production [17]. The earliest experiments led to the conclusion that sorghum could not be used to produce lager beer on account of the almost or complete absence of the $\beta$-amylase needed for malt saccharification. However, this has been questioned, as the low detectability of amylolytic enzymes resulted from using the enzymatic measurements for barley, which were unsuitable for sorghum [101, 102]. Apart from that, it has been experimentally demonstrated that after germination seeds the $\beta$-amylase activity amounted to less than $25 \%$ of its activity in barley malt, but no $\beta$-amylase activity was observed in sorghum before gelatinisation [102]. In sorghum, the enzyme was active and soluble; whereas in barley, it was fixed and inactive [103]. In African countries, sorghum is used to produce traditional beers, which differ in taste from European beers. They are characterised by high turbidity because they are not filtered. Hops are rarely used in the production process. Lactic acid bacteria are used for fermentation. In spite of this, these beers are stable and are acceptable to most consumers in Nigeria and the rest of the world [98, 104-106].

\section{Demand for gluten-free beer}

Celiac disease is usually diagnosed among Caucasians, especially in western and northern Europe. Its incidence is much lower among Africans, Japanese, and Chinese individual. It is assumed that this divergence is the result of different diets, genetic factors, and diagnostic capabilities [107]. The incidence of $\mathrm{CD}$ is increasing in Europe, where it amounts to about $0.3-3 \%$ of the population [108]. Screening tests usually show that the incidence of celiac disease is 1:100. If we assume that the incidence of celiac disease is 1:100, there would be about 8 million patients in Europe (about 2.7 million adults, including 1.6 million women). If we consider the results of screening tests on adult patients with celiac disease (33.5\% of patients) and the amount of beer produced in Europe in 2018 (392 million hl) [98], the marketing of gluten-free beer might increase beer production at least by $0.1 \%$ or even by $1 \%$-i.e., by about $0.39-3.9$ million hl per year [11].

The raw materials for beer production include maize, barley, sorghum, millet, and others (Table 3). Sorghum dominated the gluten-free beer market in 2017, and its share of the total volume of gluten-free beer produced was $37.9 \%$ [108-110]. Beer made from sorghum is obviously gluten free, which makes it preferred by the consumer, and thus increases demand in this segment [96, 98]. Gluten-free beer is an alternative not only for people intolerant to gluten, but also for those who others are interested in various new products released on the market. These people may significantly extend the market of gluten-free beer consumers. Women are a special target group because the incidence of celiac disease is higher among female patients ( $60 \%$ of adult patients), and because they are typically more concerned about healthy lifestyle, including healthy nutrition [11, 103]. According to a report published by Fior Markets, the global gluten-free beer market will increase from USD 5.6 billion in 2017 to USD 18.7 billion by 2025, with a compound annual growth rate of $16.3 \%$ during the forecast period for 2018-2025 [108, 109].

A growing awareness of the benefits of gluten-free products is the main driver of the market. Growing health concerns among consumers are paving the way for manufacturers to reach new milestones in product manufacturing. Gluten-free beer can be expected to gain increasing influence in the internet retail market over the next few years, driving market development. The high price of gluten-free 
Table 3 Commercially produced gluten-free beers

\begin{tabular}{|c|c|c|c|c|}
\hline Beer & Cereals/Pseudocereals & Brewery & Country & Reference \\
\hline O’Brien Premium Lager & Sorghum with the buckwheat & O’Brien & Australia & {$[111]$} \\
\hline Green's Discovery Amber Ale & Mix: millet, sorghum, buckwheat, rice & De Proef & Belgium & [112] \\
\hline $\begin{array}{l}\text { Green's Endeavor Dubbel } \\
\text { Green's Quest Tripel }\end{array}$ & Mix: millet, sorghum, buckwheat, brown rice & De Proef & Belgium & {$[112]$} \\
\hline La Messagère & Buckwheat, rice & New France & Canada & {$[113]$} \\
\hline Mongozo Quinua & Quinoa & Mongozo Beers & The Netherlands & [114] \\
\hline Celia Saison & Sorghum, & The Alchemist & U.S & {$[115]$} \\
\hline Dragon's Gold & Sorghum, & Bard's Tale & U.S & [116] \\
\hline New Grist & Sorghum, rice & Lakefront & U.S & {$[117]$} \\
\hline Redbridge & Sorghum & Anheuser-Busch & U.S & [118] \\
\hline
\end{tabular}

beer may however inhibit its development. Yet new product development and innovation combined with proactive marketing of gluten-free products on the part of retailers will help strengthen the market [108, 109].

Key producers in the gluten-free beer market are New Belgium Brewing Company, Inc. (the U.S.), Les Brasseurs Sans Gluten Inc. (Canada), Joseph James Brewing Company, Inc. (the U.S.), Stone Brewing Co. (the U.S.), Ground Breaker Brewing and Gastropub (the U.S.), New Planet Beer Co. (the U.S.), Brasserie De Brunehaut S.A. (Belgium), Omission Brewing Co. (the U.S.), Lakefront Brewery Inc. (the U.S.), Redbridge Beer (the U.S.), Whistler Brewing Company (Canada), Ipswich Ale Brewery (the U.S.), Dogfish Head Craft Brewery Inc. (the U.S.), Epic Brewing Company (the U.S.), and Bellfield Brewery Ltd. (the U.K.) (Table 3) [110].

\section{Conclusions}

This article presents literature data on the production of gluten-free beer using typical and atypical grains considering their potential use by people with abnormal immune response. We have dealt with diet-dependent diseases where a restrictive gluten-free diet is the only therapy. An overview has been provided of the possibilities of malting pseudocereal ingredients and assessing their potential usefulness in the production of gluten-free beer. We have also described the possibilities of gluten-free beer production from $100 \%$ barley malt using new production techniques. We have described which patients might be potential consumers of gluten-free beer. The ingredients, conditions, and methods of processing can lead to differences in the qualitative parameters of malt and beer. These factors determine the properties of the final product and its acceptability to consumers. Optimising these conditions may result in the development of a product that will fill the market niche of goods for people intolerant to gluten and patients with celiac disease. Such a product will also meet FDA requirements concerning the production of beer from gluten-free ingredients and will receive sensory acceptance from consumers. A crucial element in gluten-free beers is their taste, which for pseudocereals significantly differs from the taste of traditional beers. Techniques for the production of gluten-free beers from barley malt are, thus, undergoing constant refinement, with the goal of being able to market them as gluten-free beers that meet the FDA requirements.

\section{Compliance with ethical standards}

Conflict of interest The authors declare that they have no conflict of interest.

Compliance with ethics requirements The autor declare compliance with ethics requirements.

Open Access This article is licensed under a Creative Commons Attribution 4.0 International License, which permits use, sharing, adaptation, distribution and reproduction in any medium or format, as long as you give appropriate credit to the original author(s) and the source, provide a link to the Creative Commons licence, and indicate if changes were made. The images or other third party material in this article are included in the article's Creative Commons licence, unless indicated otherwise in a credit line to the material. If material is not included in the article's Creative Commons licence and your intended use is not permitted by statutory regulation or exceeds the permitted use, you will need to obtain permission directly from the copyright holder. To view a copy of this licence, visit http://creativecommons.org/licenses/by/4.0/.

\section{References}

1. Sharma N, Bhatia S, Chunduri V, Kaur S, Sharma S, Kapoor P, Kumari A, Garg M (2020) Pathogenesis of celiac disease and other gluten related disorders in wheat and strategies for mitigating them. Front Nutr 7:6. https://doi.org/10.3389/ fnut.2020.00006 
2. Lebwohl B, Cao Y, Zong G, Hu FB, Green PHR, Neugut AI, Rimm EB, Sampson L, Dougherty LW, Giovannucci E, Walter C, Willett WC, Chan AT (2017) Long term gluten consumption in adults without celiac disease and risk of coronary heart disease: prospective cohort study. BMJ 357:1892. https://doi.org/10.1136/ bmj.j1892

3. Cabanillas B (2019) Gluten-related disorders: Celiac disease, wheat allergy, and non-celiac gluten sensitivity. Crit Rev Food Sci Nutr 12:1-16

4. Brzozowski B, Bednarski W, Adamczak M (2005) Biotechnological modification of biological properties of proteins in cereals. Food Sci Technol Quality 4(45):17-26 (in Polish)

5. Kenrick K, Day AS (2014) Coeliac disease: where are we in 2014? Aust Fam Physician 43(10):674-678

6. Juhasz A, Belova T, Florides CG, Maulis C, Fischer I, Gell G, Birinyi B, Ong J, Keeble-Gagnère G, Maharajan A, Ma W, Gibson P, Jia J, Lang D, Mayer KFX, Spannagl M, Tye-Din JA, Appels R, Olsen OA (2018) Genome mapping of seed-borne allergens and immunoresponsive proteins in wheat. Sci Adv 4(8):eaar8602. https://doi.org/10.1126/sciadv.aar8602

7. Collin P, Thorell L, Kaukinen K, Maki M (2004) The safe threshold for gluten contamination in gluten-free products. Can trace amounts be accepted in the treatment of celiac disease? Aliment Pharmacol Ther 19:1277-1283

8. Kupper C (2005) Dietary guidelines and implementation for celiac disease. Gastroenterology 128(4):7-21

9. Podeszwa T (2013) The use of pseudocereals for the productionof gluten-free beer. Eng Sci Technol 3(10):92-102 (in Polish)

10. Chlebicka A, Fałkowski J, Lichota J (2018) From Macro to micro: the change of trendsetters in the Polish beer market. In: Garavaglia C, Swinnen J (eds) Economic perspectives on craft beer. Palgrave Macmillan, Cham

11. Kawka A, Achremowicz B (2014) Oats-a plant of the 21st century. Nutritional and industrial use. NTP 8(3):\#41. https://www. npt.up-poznan.ne (in Polish)

12. Swora-Cwynar E, Marciniak M, Mańkowska-Wierzbicka D, Gulbicka P, Grzymisławski M, Dobrowolska A (2019) New aspects of celiac disease - epidemiology, diagnostics, symptoms. Forum Zaburzeń Metabolicznych 10(1):29-36 (in Polish)

13. Arendt EK, Dal Bello F (2008) Gluten-free cereal products and beverages. Academic Press, Elsevier

14. De Meo BG, Freeman O, Marconi C, Booer GP, Fantozzi P (2012) Behaviour of malted cereals and pseudo-cereals for gluten-free beer production. J Inst Brew 117(4):541-547

15. Walker MM, Ludvigsson JF, Sanders DS (2017) Coeliac disease: review of diagnosis and management. Med J Aust 207(4):173-178

16. Van Heel D, West J (2006) Recent advances in celiac disease. Gut 55(7):1037-1046

17. Rubio-Flores M, Serna-Saldivar SO (2016) Technological and engineering trends for production of gluten-free beers. Food Eng Rev 8:468-482

18. DeGeorge KC, Frye JW, Stein JM, Rollins LK, McCarter DF (2017) Celiac disease and gluten sensitivity. Prim Care 44:639-707

19. Jericho H, Assiri A, Guandalini S (2017) Celiac disease and wheat intolerance syndrome: a critical update and reappraisal. J Pediat Gastroenterol Nutr 64(1):15-21

20. Malamut G, Cording S, Cerf-Bensussan N (2019) Recent advances in celiac disease and refractory celiac disease. F1000Res 8:F1000 Faculty Rev-969. https://doi.org/10.12688/ f1000research.18701.1 (Published 2019 Jun 26)

21. Schuppan D, Junker Y, Barisani D (2009) Celiac disease: from pathogenesis to novel therapies. Gastroenterology 137(6): 1912-1933
22. Sardarodiyan M, Ataye Salehi E (2016) Celiac disease and role of a gluten-free diet. Int J Pharm Tech Res 9(4):349-356

23. Capili B, Chang M, Anastasi JK (2014) A clinical update: nonceliac gluten sensitivity-is it really the gluten? J Nurse Pract 10(9):666-673

24. Jnawali P, Kumar V, Tanwar B (2016) Celiac disease: overview and consideration for development of gluten-free foods. Food Sci Human Wellnes 5:169-176

25. de Lourdes MM, Commino I, Sousa C (2014) Alternative grains as potential raw material for gluten-free food development in the diet of celiac and gluten sensitive patient. Austin J Nutri Food Sci 2(3): 1016

26. Ludvigsson JF, Leffler DA, Bai JC, Biagi F, Alessio Fasano PHR, Green HM, Kaukinen K, Kelly CP, Leonard JN, Aslaksen Lundin KE, Murray JA, Sanders DS, Walker MM, Zingone F, Ciacci C (2013) The Oslo definitions for coeliac disease and related terms. Gut 62:43-52

27. Catassi C, Bai JC, Bonaz B, Bouma G, Calabrò A, Carroccio A, Castillejo G, Ciacci C, Cristofori F, Dolinsek J, Francavilla R, Elli L, Green P, Holtmeier W, Koehler P, Koletzko S, Meinhold C, Sanders D, Schumann M, Schuppan D, Ullrich R, Vécsei A, Volta U, Zevallos V, Sapone A, Fasano A (2013) Non-Celiac Gluten sensitivity: the new frontier of gluten related disorders. Nutrients 5(10):3839-3853

28. Stamnaes J, Sollid LM (2015) Celiac disease: autoimmunity in response to food antigen. Semin Immunol 27(5):343-352

29. Kelly PC, Dennis M (2020) Patient education: celiac disease in adults (Beyond the Basics). https://www.uptodate.com/conte nts/celiac-disease-in-adults-beyond-the-basics

30. Caio G, Volta U, Sapone A, Leffler DA, De Giorgio R, Catassi C, Fassano A (2019) Celiac disease: a comprehensive current review. BMC Med 17(1):142

31. Żebrowska A, Waszczykowska E, Kowalewski C, Woźniak K, Olszewska M, Placek W, Czajkowski R, Szepietkowski J, Białynicki-Birula R, Dmochowski M (2016) Diagnostic and terapeutic guidelines of dermatis herpetiformis (Duhring's disease)—consensus of Polish. Dermatol Rev 103:95-101

32. Prasant $\mathbf{J}$ (2014) A review on dermatitis herpetiformis. Inter $\mathbf{J}$ Pharma Res Rev 3(3):72-78

33. Caproni M, Bonciolini V, D'Errico A, Antiga E, Fabbri P (2012) Celiac disease and dermatologic manifestations: many skin clue to unfold gluten-sensitive enteropathy. Gastroentol Res Pract. https://doi.org/10.1155/2012/952753

34. Jimenez A, Hull Ch, Zone J (2019) Dermatitis herpetiformis resistant to dapsone due to dietary iodide ingestion. JAAD Case Reports 5(8):713-714

35. Volta U, Caio G, Tovoli F, DeGiorgio R (2013) Non-celiac gluten sensitivity: questions still to be answered despite increasing awareness. Cell Mol Immunol 10(5):383-392

36. Husby S, Murray J (2015) Non-celiac gluten hypersensitivity: what us all the fuss about? F1000Prime Rep. https://doi. org/10.12703/P7-54

37. Hozyasz KK (2016) Non-celiac gluten sensitivity (NCGS) —an old diagnosis recently rediscovered. Fam Med Prim Care Rev 18(1):79-83

38. Nucera E, Aruanno A, Ianiro G, Cammarota G, Gasbarrini A, Schiaviano D (2018) Wheat desensitization treatment in patients with gluten sensitivity. Adv Dermatol Allergol 35(3):320-322

39. Czaja-Bulsa G (2015) Non celiac gluten sensitivity-a new disease with gluten intolerance. Clin Nutr 34:189-194

40. Roszkowska A, Pawlicka M, Mroczek A, Bałabuszek K, Nieradko-Iwanicka B (2019) Non-celiac gluten sensitivity: a review. Medicina (Kaunas) 55(6):222. https://doi.org/10.3390/ medicina55060222 
41. Alhassan E, Yadav A, Kelly CP, Mukherjee R (2019) Novel nondietary therapies for celiac disease. Cell Mol Gastroenterol Hepatol 8(3):335-345

42. Makharia GK (2014) Current and emerging therapy for celiac disease. Front Med 1:6. https://doi.org/10.3389/fmed.2014.00006

43. Sollid LM, Qiao SW, Anderson RP, Gianfrani C, Koning F (2012) Nomenclature and listing of celiac disease relevant gluten T-cell epitopes restricted by HLA-DQ molecules. Immunogenetics 64(6):455-460

44. Rashtak S, Murray JA (2012) Review article: coeliac disease, new approaches to therapy. Aliment Pharmacol Ther 35:768-781

45. Shan L, Marti T, Sollid LM, Gray GM, Khosla C (2004) Comparative biochemical analysis of three bacterial prolyl endopeptidases: implications for coeliac sprue. Bioch J 383(2):311-318

46. Krishnareddy S, Stier K, Recanati M, Lebwohl B, Green PH (2017) Commercially available glutenases: a potential hazard in coeliac disease. Ther Adv Gastroenterol 10(6):473-4811

47. Salden BN, Monserrat V, Troost FJ, Bruins MJ, Edens L, Bartholomé R, Haenen GR, Winkens B, Koning F, Masclee AA (2015) Randomised clinical study: Aspergillus niger-derived enzyme digests gluten in the stomach of healthy volunteers. Aliment Pharmacol Ther 42(3):273-285

48. König J, Brummer RJ (2018) Is an enzyme supplement for celiac disease finally on the cards? Expert Rev Gastroenterol Hepatol 12(6):531-533

49. Yoosuf S, Makharia GK (2019) Evolving therapy for celiac disease. Front Pediatr. https://doi.org/10.3389/fped.2019.00193

50. Liu H, Fan X, Song H, Hu X, Zhang G, Yu Ch, Yi L (2019) Efficient production of gluten hydrolase Kuma030 in E. coli by hot acid treatment without chromatography. En Microbial Technol 129:109356. https://doi.org/10.1016/j.enzmi ctec.2019.05.013

51. Gessendorfer B, Koehler P, Wieser H (2009) Preparation and characterization of enzymatically hydrolyzed prolamins from wheat, rye and barley as references for the immunochemical quantitation of partially hydrolyzed gluten. Anal Bioanal Chem 395(6): 1721-1728

52. Mikołajczak N (2018) Campatibility of labelling gluten-free food products with current legal provisions based on the review of information on the labels. J Edu Health Sport 8(9):888-903

53. Codex Alimentarius International Food Standards. Standard for foods for special dietary use for persons intolerant to gluten. Codex Stan 118-1979

54. Vassiliou A (2009) Commission Regulation (EC) No 41/2009 of 20 January 2009 concerning the composition and labelling of foodstuffs suitable for people intolerant to gluten. Off J Eur Union 21:L16

55. Saturni L, Ferretti G, Bacchetti T (2010) The gluten-free diet: safety and nutritional quality. Nutrients $2: 16-34$

56. Federal Register Food labelling: gluten-free labeling of fermented or hydrolyzed foods. Food and Drug Administration on 11/18/2015 Docket No. FDA-2014-N-1021 https://www.regul ations.gov Accessed 11/18/2015

57. Kerpes R, Fischer S, Becker T (2017) The production of gluten-free beer: degradation of hordeins during malting and brewing and the application of modern process technology focusing on endogenous malt peptidases. Trends Food Sci Technol 69:129-138

58. Harasym J, Pieciuń T (2010) Atypical brewing malts-a review. Eng Sci Technol 92:77-91

59. Meo B, Freeman G, Marconi O, Booer C, Perretti G, Fantozzi $P$ (2011) Behaviour of malted cereals and pseudo-cereals for gluten-free beer production. J Inst Brew 117(4):541-546

60. Wijngard HH, Arendt EK (2006) Optimisation of a mashing program for $100 \%$ malted buckwheat. J Inst Brew 112(1):57-65
61. Yeo HQ, Liu S-Q (2014) An overview of selected specialty beers: developments, challenges and prospects. I Food Sci Technol 49(7):1607-1618

62. Mayer H, Ceccaroni D, Marconi O, Sileoni V, Perretti G, Fantozzi P (2016) Development of an all rice malt beer: a gluten free alternative. LWT Food Sci Technol 67:67-73

63. Cela N, Condelli N, Caruso MC, Perretti G, Di Cairano M, Tolve R, Galgano F (2020) Gluten-free brewing: issues and perspectives. Ferment 6(2):53. https://doi.org/10.3390/ferme ntation6020053

64. Hager AS, Taylor JP, Waters DM, Arendt EK (2014) Gluten free beer-a review. Trends Food Sci Technol 36(1):44-54

65. Benítez EI, Acquisgrana MR, Peruchena NM, Sosa GL, Lozano JE (2016) Effects of silica gel on reduction in gluten during several beer brewing stages. I J Food Sci Technol 51(4):920-928

66. Taylor JP (2016) Development of a toolbox for the reduction of hordeins in barley malt beers. PhD Thesis, University College Cork. Doctoral thesis. https://hdl.handle.net/10468/3241

67. Van Landschoot A (2011) Gluten-free barley malt beers. Cerevisia 36(3):93-97

68. Guerdrum LJ, Bamforth CW (2012) Prolamin levels through brewing and the impact of prolyl endoproteinase. J Am Soc Brew Chem 70(1):35-38

69. Tanner GJ, Colgrave ML, Howitt CA (2014) Gluten, celiac disease, and gluten intolerance and the impact of gluten minimization treatments with prolylendopeptidase on the measurement of gluten in beer. J Am Soc Brew Chem 72(1):36-50

70. Hartmann G, Koehler P, Wieser H (2006) Rapid degradation of gliadin peptides toxic for coeliac diseasepatients by proteases from germinating cereals. J Cereal Sci 44(3):368-371

71. Kerpes R, Knorr V, Procopio S, Koehler P, Becker T (2016) Gluten-specific peptidase activity of barley as affected by germination and its impact on gluten degradation. J Cereal Sci 68:93-99

72. Knorr V, Kerpes R, Wieser H, Zarnkow M, Becker T, Koehler P (2016) Production and application of barley malt extract with high peptidase activity for the degradation of gluten in worth. Eur Food Res Technol 242:585-597

73. Albanese L, Ciriminna R, Meneguzzo F, Pagliaro M (2017) Beerbrewing powered by controlled hydrodynamic cavitation: theory and real-scale experiments. J Cle Pro 142(4):1457-1470

74. Albanese L, Ciriminna R, Meneguzzo F, Pagliaro M (2017) Gluten reduction in beer by hydrodynamic cavitation assisted brewing of barley malts. LWT-Food Sci Technol 82:342-353

75. Comino I, de Lourdes MM, Sousa C (2015) Role of oats in celiac disease. World J Gastroenterol 21(41):11825-11831

76. Aaltonen K, Laurikka P, Huhtala H, Mäki M, Kaukinen K, Kurppa K (2017) The long-term consumption of oats in celiac disease patients is safe: a large cross-sectional study. Nutriens 9(6):611. https://doi.org/10.3390/nu9060611

77. Hoffmanová I, Sánchez D, Szczepanková A, Tlaskalová-Hogenová H (2019) The pros and cons of using oat in a glutenfree diet for celiac patients. Nutrients 11(10):2345. https://doi. org/10.3390/nu11102345

78. Fritz RD, Chen Y (2018) Oat safety for celiac disease patients: theoretical analysis correlates adverse symptoms in clinical studies to contaminated study oats. Nutr Res 60:54-67

79. Pawłowska P, Diowksz A, Kordialik-Bogacka E (2013) Glutenfree oat malt as a brewing raw material. Food Sci Technol Quality $1(86): 181-190$

80. Pawłowska P, Diowksz A, Kordialik- Bogacka E (2012) Stateof-the-art incorporation of oats into a gluten-free diet. Food Rev Internat 28(3):330-342 
81. Pawłowska P, Diowksz A, Kordialik-Bogacka E (2012) Oats in a gluten-free diet. New trends in life sciences. Creativetime, Kraków

82. Schnitzenbaumer B, Arendt EK (2014) Brewing with up to $40 \%$ unmalted oats (Avena sativa) and sorghum (Sorghum bicolour): a review. J Inst Brew 120:315-330

83. Dziedzic K, Drożdżyńska A, Górecka D, Czaczyk K (2009) Contents of some selected antioxidants in buckwheat and products produced during its processing. Food Sci Technol Quality 16(6):81-90

84. Alvarez-Jubete L, Arend EK, Gallagher E (2010) Nutritive value of pseudocereals and their increasing use as functional glutenfree ingrediens. Trends Food Sci Technol 21:106-113

85. Starowicz M, Koutsidis G, Zielińsk H (2018) Sensory analysis and aroma compounds of buckwheat containing products-a review. Crit Rev Food Sci Nutr 58(11):1767-1779

86. Manzatti N, Alencar M, De Carvalho OL (2019) Advances in pseudocereals: crop cultivation, food application, and consumer perception. Bioactive Molecules Food. Springer Internation Pub, New York

87. Zweytick G, Sauerzopf E, Berghofer E (2005) Production of gluten-free beer. Book of Abstracts: AACC Annual Meeting 2005, American Assoc. Cer. Chemists, Orlando, 11-14 Sept 2005

88. Nic Phiarais BP, Mauch A, Schehl BD, Zarnkow M, Gastl M, Herrmann M, Zannini E, Arendt EK (2010) Processing of a top fermented beer brewed from $100 \%$ buckwheat maltwith sensory and analytical characterisation. J Inst Brew 116(3):256-274

89. Tang Y, Tsao R (2017) Phytochemicals in quinoa and amaranth grains and their antioxidant, anti-inflammatory, and potential health beneficial effects: a review. Mol Nutr Food Res. https:// doi.org/10.1002/mnfr.201600767

90. Wolosik K, Markowska A (2019) Amaranthus cruentus taxonomy, botanical description, and review of its seed chemical composition. Nat Prod Commun. https://doi.org/10.1177/19345 78X19844141

91. Paśko P, Barton H, Zagrodzki P, Gorinstein S, Fołta M, Zachwieja Z (2009) Anthocyanins, total polyphenols and antioxidant activity in amaranth and quinna seeds and sprouts turing their growth. Food Chem 115:994-998

92. Venskutonis PR, Kraujalis P (2013) Nutritional components of amaranth seeds and vegetables: a review on composition, properties, and uses. Compr Rev Food Sci Food Safety 12(4):381-412

93. Acuña-Gutiérrez C, Campos-Boza S, Hernández-Pridybailo AM, Jiménez V (2019) Nutritional and industrial relevance of particular neotropical pseudo-cereals. Food Tech Transitions. https:// doi.org/10.1007/978-3-030-21059-5_4

94. Satheesh N, Fanta SW (2018) Review on structural, nutritional and anti-nutritional composition of Teff (Eragrostis tef) in compar ison with Quinoa (Chenopodium quinoa Willd). Food Sci Technol 4(1):1546942. https://doi.org/10.1080/23311 932.2018.1546942

95. Kordialik-Bogacka E, Bogdan P, Pielech-Przybylska K, Michałowska D (2018) Suitability of unmalted quinoa for beer production. J Sci Food Agric 98(13):5027-5036

96. Ceccaroni D, Marconi O, Sileoni V, Wray E, Perretti G (2019) Rice malting optimization for the production of top-fermented gluten-free beer. J Sci Food Agric 99:2726-2734

97. Aisen AO (1988) Sorghum: a suitable source for brewing beer. Brew Distill Int 3:20-22

98. Illori MO, Ogundiwin JO, Adewusi SRA (1991) Sorghum malt brewing with sorghum/maize adjuncts. Brew Distill Int 3(10): $10-13$

99. Aisen AO, Muts GCJ (1987) Micro-scale malting and brewing studies of same sorghum varieties. J Inst Brew 93:328-331
100. Novellie L (1962) Kafficorn malting ad brewing: efect of malting conditions on malting losses and amylase activities of kaffircorn malts. J Sci Food Agric 13:121-126

101. Okon EU, Uwaifo AO (1984) Partial purification and proportions of beta-amylase isolated from Sorghum bicolour (L) Moench. J Agric Food Chem 32:11-15

102. Taylor JRN, Robbins DJ (1993) Factors influencing beta-amylase activity in sorghum malt. J Inst Brew 99(5):413-416

103. Taylor SL, Baumert JL, Kruzinga AG, Remington BC, Crevel RWR, Brooke-Taylor S, Allen HJ, Houbenet G (2014) Establishment of reference doses for residues of allergenic foods: report of the vital expert panel. Food Chem Toxicol 63:9-17

104. Hager AS, Josh P, Taylor D, Waters M, Arendt EK (2014) Gluten free beer-a review. Trends Food Sci Technol 36(1):44-54

105. Konfo ChTR, Chabi N, Dahouenon-Ahoussi E, Cakpo-Chichi M, Mansourou SM, Sohounhloue KDC (2015) Improvement of African traditional sorghum beers quality and potential applications of plants extracts for their stabilization: a review. J Microbiol Biotechnol Food Sci 5(2):190-196

106. Tye-Din JA, Galipeau HJ, Agardh D (2018) Celiac disease: a review of current concepts in pathogenesis, prevention, and novel therapies. Front Pediatr. https://doi.org/10.3389/fped.2018.00350

107. Diez-Sampedro A, Olenick M, Maltseva T, Flowers M (2019) A gluten-free diet, not an appropriate choice without a medical diagnosis. J Nutr Metabolism. https://doi. org/10.1155/2019/2438934

108. The Beer industry embraces growing gluten free market, The European Beer Challenge 2019 London. https://europeanbeercha llenge.org

109. Global gluten-free beer market is expected to reach USD 18.7 Billion by 2025 : Fior Markets, reports. https://www.globenewsw ire.com/newsrelease

110. Gluten-free beer market research Report - Forecast 2023, reports. https://www.marketresearchfuture.com/reports/glute n-free-beer-market-7144

111. O'Brien gluten-free beers. Australia. https://chrisshanahan.com/ articles/2012/obrien-gluten-free-beers/

112. De Proef Brewery. Belgium. https://merchantduvin.com/brewgreens-endeavour-dubbel-gluten-free-ale.php. Accessed May 2020

113. Beer review 2: La messagère gluten-free beer. Quebec, Canada. https://mbtreviews.wordpress.com/2011/07/19/beer-revie w-2-la-messagere-gluten-free-beer-quebec-canada/. Accessed May 2020

114. Saveur-biere. The Netherlands. https://www.saveur-biere.com/en/ bottled-beer/1804-mongozo-quinoa.html. Accessed May 2020

115. A review of Ipswich ale brewery. Brewed in Massachusetts. https ://www.bestglutenfreebeers.com/gluten-free-beer-review-ipswi ch-ale-brewery-celia-saison/. Accessed May 2020

116. Bard's Tale Beer Company. Gluten-free. US. https://untap pd.com/b/bard-s-tale-beer-company-bard-s-tale-dragonsgold/7757. Accessed May 2020

117. Lakefront Brewery. INC. US. https://www.newgrist.com. Accessed May 2020

118. Redbridge gluten-free beer. Anheuser-Busch's Sorghum-Based Brew. https://www.bestglutenfreebeers.com/anheuser-busch -redbridge. Accessed May 2020

Publisher's Note Springer Nature remains neutral with regard to jurisdictional claims in published maps and institutional affiliations. 